\title{
Men's Involvement on Promoting Gender Equality: Case Study of Campaign by "Laki-Laki Peduli” in Indonesia
}

\author{
Detta Rahmawan ${ }^{1}$, Eni Maryani ${ }^{1}$, Preciosa Alnashava $\mathrm{J}^{1}$ \\ ${ }^{1}$ Faculty of Communication Science, Universitas Padjadjaran, Bandung - Indonesia
}

\begin{abstract}
Men can take parts in promoting the agenda of gender equality in many ways, ranging from; grassroots campaigns, advocacy, and education programs. In Indonesia, one of the few movements which particularly prominent is a campaign by Laki-Laki Peduli (LLP). This research used qualitative descriptive approach to explore and analyze the strategy that has been used by LLP's campaign, especially on how they used various media to construct a message which can be accepted by Indonesian society who's still largely embraces patriarchal culture. It has been found that LLP's use TVC and short movies to amplify their message on the importance of fatherhood, showing a more positive concept of masculinity, and to encourage men to play an active role in becoming partners with their wives. Furthermore, they also utilize various digital media to help spread the awareness about the importance of men's involvement on gender equality.
\end{abstract}

Keywords: Gender Equality; Fatherhood; Men's involvement; Activism.

\section{Introduction}

It can be said that the gender equality movement required men's involvement [1]. Involving men, can also make the issues of gender equality do not being viewed exclusively only for the interest of women [2]. In Indonesia, one of the initiative regarding men's involvement in promoting gender equality has been done by "men that care" or Laki-Laki Peduli,(which will be referred to as "LLP" in this article). LLP is a subsidiary program on a global fatherhood campaign which have been active in more than 40 countries called "MenCare". LLP primarily tries to reconstruct the concepts of masculinity in Indonesia as well as encourage men to become "more involved fathers, more invested partners, and to embrace the empowerment of the women and girls in their lives" [3].

In a patriarchal culture, male involvement in various programs which aimed at promoting gender equality can be challenging. Men as the head of the households is often seen only in the context of providing material needs, such as money, to the family without needing to be actively involved in child care or domestic affairs. Interestingly, In Indonesia, such stereotype still can be seen both in big cities and in rural areas. Hence, the programs that aim to break the taboo about the role of men in the household as being done by LLP is important and relevant.

Men's involvement programs on gender equality have been conducted in various ways and agendas. However, it can be said that there are limited studies related to men's involvement program in the context of Indonesia. Most of the literature within the topic is derived from NGO reports, and many study focused on the role of men associated with violence against women.

Men's involvement in women's movement in order to promote gender equality can be done through many ways, including participation in grassroots movements and education programs, supporting government initiatives in making policies regarding gender equality [4] and involvement in better parenthood [5]. There are three key arguments in feminist rationale regarding men's involvement in ending violence against women. First argument, essentially it is men who commit the violence. Hence, the efforts to change men's attitudes, behaviors, identities, and relations against women are needed. Secondly, men's involvement is relevant because there is a construction of masculinity which often associated with patriarchal, and sexist attitudes. The third argument address the fact that violence as a problem that affects both women and men [4].

The decision to use a variety of media, including digital media in the dissemination of LLP's message are based on the facts that Digital Media, especially Social Media is very popular among Indonesian. Various reports suggest that over the years, the growth of people who use social media in Indonesia is considerably high [6].

Digital media can serve as a medium for public participation in a range of ways [7], it also can "[change]

*Corresponding author: detta@unpad.ac.id 
the citizen from being a beneficiary of change to becoming an agent of change" [8]. While it can be said that various platforms are being used in digital activism, social media such as Facebook, Twitter, YouTube, and many others are especially important and frequently utilized [7][8][9].

The case of 'Women's March 2017' in Jakarta [10] shows digital media's role in helping to create offline protests in a massive scale. Furthermore, several genderbased movement initiatives today has been utilizing social media for disseminating articles, calling for participation on specific event, networking and fund raising [11]. Hence, it can be said that Indonesia has the opportunity to use digital media for social and political issues, including gender equality.

Gender equality lead by feminist who concentrate on women's welfare, freedom, and equality. Feminist thought and movement not only focus on equality but also environmental issue. Feminist movement called ecofeminism. According to feminism environmental exploitation is closely related to women's exploitation.

\section{Methodology}

This research uses qualitative approach to explore in detail men's involvement in promoting the issue of gender equality in Indonesia. Data were collected from documentation and analysis from Laki-Laki Peduli's website lakilakipeduli.org, their Social Media account, various news related to the campaign, as well as literature reviews.

\section{Discussion}

Our analysis show that there are several strategies done by LLP. The first strategy is building networks with other similar initiatives that already exist in Indonesia, such as the Pulih Foundation and a New Male Alliance. The idea of men's involvement on gender equality are disseminated through events, trainings, seminars, and discussions.

LLP is also quite active on Twitter at twitter.com/laki2peduli, Facebook at www.facebook.com/Lakilakipeduli, and also YouTube at youtube.com/channel/UCXK6Oo8L0FVq8k771CfH-YQ. On their Twitter and Facebook account, LLP consistently talk about the various ways for men to be involved in supporting gender equality, as well as promoting their events to larger audiences. They used YouTube to store the recording of their events, and sometimes, LLP also did a Live Streaming via YouTube which was then posted on Twitter and Facebook. This shows that LLP utilizes a variety of digital technologies to make their messages reachable by as many audiences as possible.

One of the main focuses of LLP is the involvement of men in eliminating violence against women. This is done by redefining the meaning of 'masculinity' and the role of fatherhood. Furthermore, LLP also constantly spread these ideas to teenage boys aged 18-25 years, with the campaign called \#GenerasiJagoan or "Whiz Generation". The campaign tried to generate a more positive concept on masculinity and promoting antiviolence attitudes and behavior. LLP also often provide seminars related to sexual and reproductive health education for teenagers.

In redefining masculinity, LLP also often emphasizes that it is important for men to pay more attention to their feelings, and to understand that men do not always have to look 'tough'. Hence, they provide counseling services for men. This is important because there is a belief that men do not need space for emotion, to share feelings with others.

Topics on fatherhood and the role of father also gets a sizable portion on LLP's movement. For example, they created two public service ads regarding the role of men as father and husband. The first advertisement shows involvement of the father in the process of labor, and the second advertisement illustrates the importance of planned parenthood. Moreover, LLP also makes some modules about fatherhood which is used in their training programs.

To give illustration on how the idea of gender equality practiced in everyday life, LLP created a short film entitled "A Little Piece of Heaven in Bondowoso". This film shows a cleric (religious teacher) in Bondowoso, Indonesia, who upholds gender equality, women's rights and also engaging men in domestic work in his community. The video shows the life of Ustadz Muhamad Nursalim and his wife Ustadzah Nur Fadlilah who is a kindergarten and junior high school teacher. Ustadz Muhammad decided to be a kind of stay-at-home dad, teaching the Koran at home and carry out domestic duties.

At first, the villagers had a strange feeling to see a man, a religious teacher, drying and washing clothes, sweeping, and cooking at home, since, doing housework is often associated as a female, wife's duty. Yet, such the film shows that a behavior that was once considered weird, gradually became natural. Ustadz Muhamad also depicted often invites men in his neighborhood to discuss about a fair division of roles in the family, and to become an involved father.

This short film is interesting because it shows how the idea of gender equality can actually go hand in hand with socio-cultural conditions in Indonesian society. The decision to use a cleric as a representation of Muslim community is to show that gender equality can exist within the values of Islam as the majority religion in Indonesia. The film is also tried to break the assumption which usually exist among the people of Indonesia that is gender equality and feminism are conflicting with Indonesian culture or Islamic values. 


\section{Conclusion}

Men can support the idea of gender equality in many ways, ranging from; grassroots campaigns, advocacy, and education programs. In Indonesia, one of the few men's involvement campaign has been done by "Men that Care" or Laki-Laki Peduli (LLP). LLP is part of "MenCare", a global fatherhood campaign which have been working to promote men's involvement mainly in fatherhood, and ending violence against women [11]

By using qualitative descriptive approach, this article analyzes the communication strategy that has been used by LLP's campaign, how they utilized media, and how they construct their messages. We found that there are several strategies that have been done by LLP, for example. They often create events, trainings, seminars, and discussions, as well as networking with other similar initiatives, e.g. the Pulih Foundation and a new male alliance. LLP also create various television commercial (TVC) and short film to amplify their message on the importance of fatherhood, and more positive concept of masculinity. Moreover, to help the messages spread further, they utilize various digital media such as Twitter, Facebook and YouTube. There are few studies related to men's involvement on gender equality in the context of Indonesia. Hence, we hope this article can be one of the references on men's involvement initiatives in Indonesia. Finally, we expect further research with similar theme that can be done using different methods and research subjects to enhance the knowledge of men's involvement in gender equality movement in Indonesia.

\section{References}

1. M. Flood, Involving Men in Efforts to End Violence Against Women. Men and Masculinities, Men and Masculinities, Sage Journals, 14(3), 358-377 (2011).

2. E. Esplen, Engaging Men in Gender Equality: Positive Strategies and Approaches, BRIDGE (development - gender), Institute of Development Studies - University of Sussex, Brighton (2006).

3. L. Burrows, From Atlas of The Future, Retrived from https://atlasofthefuture.org/project/mencare/ September 12, 2017 (2015).

4. M. Flood, Engaging men: Strategies and dilemmas in violence prevention education among men, Women Against Violence, 13, 25-32 (2002).

5. S. Thamar van Bemmelen, State of World's Father's Country Report: Indonesia 2015, Rutgers WPF Indonesia, Jakarta, Indonesia (2015).

6. APJII, Infografis Penetrasi \& Perilaku Pengguna Internet Indonesia 2016, Asosiasi Penyelenggara Jasa Internet Indonesia, Jakarta (2016).

7. M. Joyce, Digital Activism Decoded: The New Mechanics of Change, International Debate Education Association, New York (2010).
8. D. Asmarani, A new push for women's rights, Retrieved from https://sr-indonesia.com on April 15, 2017 (2016).

9. S. Nishant, Sneha, P. Purayil, \& Chattapadhyay, Sumandro, Digital Activism in Asia Reader, Meson Press, Lüneburg (2015).

10. M. Lim, Many Clicks but Little Sticks: Social Media Activism in Indonesia, J. C. A., 636-657(2013).

11. D. Asmarani, Magdalene.co", Retrieved from http://magdalene.co on September 8, 2017 (2017).

12. MenCare, About MenCare, Retrived from https://men-care.org on September 10, 2017 (2017).

13. Laki laki Peduli. Retrived from https://www.youtube.com on September 11, 2017 (2017).

\footnotetext{
Corresponding author: detta@unpad.ac.id
} 